\title{
ॠUSGS
}

\section{The National Map}

The U.S. Geological Survey (USGS) is committed to meeting the Nation's needs for current base geographic data and maps. Our vision is that, by working with partners, we will provide the Nation with access to current, accurate, and nationally consistent digital data and topographic maps derived from those data. This synthesis of information, products, and capabilities, The National Map, will be a seamless, continuously maintained set of geographic base information that will serve as a foundation for integrating, sharing, and using other data easily and consistently.

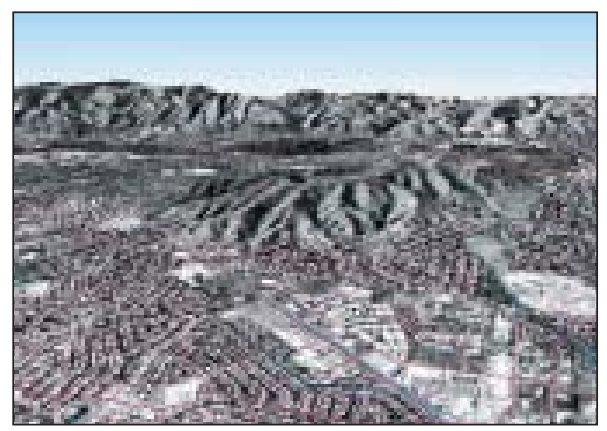

\section{The Nation Needs The National Map}

Governments depend on a common set of base information that describes the Earth's surface and locates features. They use this information as a tool for economic and community development, land and natural resource management, and health and safety services. Federal functions ranging from emergency management and defense to environmental protection rely on this information. Private industry, nongovernmental organizations, and individual citizens also use the same geographic data. Geographic information underpins an increasingly large part of the Nation's economy.

\section{USGS Role}

The most widely known form of geographic base information for the
United States is the USGS primary series topographic map. The USGS has produced more than 55,000 unique map sheets and approximately 220,000 digital orthorectified aerial images to cover the Nation. These maps and images are a national treasure, but the average primary series topographic map is 23 years old. Frequent changes on the landscape mean that many of these maps are no longer accurate and complete. The USGS is committed to organizing and leading cooperative activities to ensure that current geographic base information is readily available and useful.

\section{A New Vision}

The National Map will provide data about the United States and its territories that Federal agencies can extend, enhance, and reference as they concentrate on maintaining other data that are unique to their mission needs. The National Map will promote cost effectiveness by minimizing the need to find, develop, integrate, and maintain geographic base data each time they are needed.

\section{Under USGS leadership, The National} Map will provide data and operational capabilities that include the following:

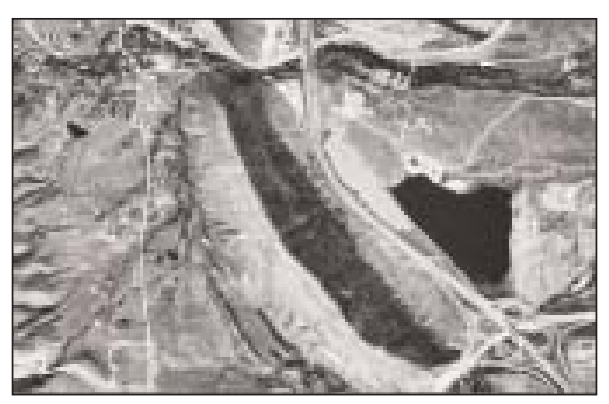

- High-resolution digital orthorectified imagery that will provide some of the feature information content now symbolized on topographic maps.

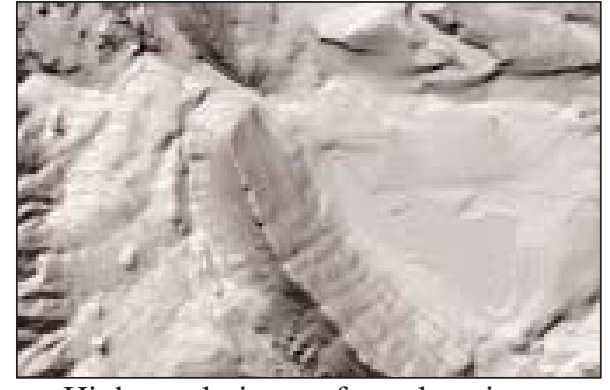

- High-resolution surface elevation data to derive contours for primary series topographic maps and to support production of accurate orthorectified imagery.

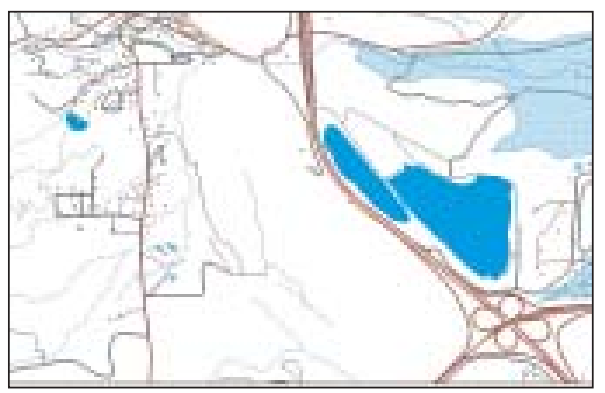

- Vector feature data for hydrography, transportation (roads, railways, and waterways), structures, government unit boundaries, and publicly owned lands boundaries.

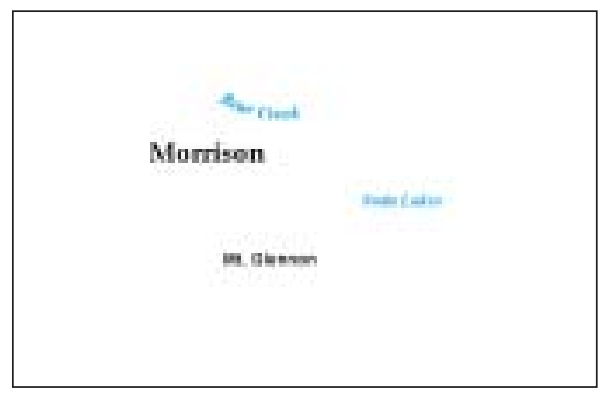

- Geographic names for physical and cultural features. 


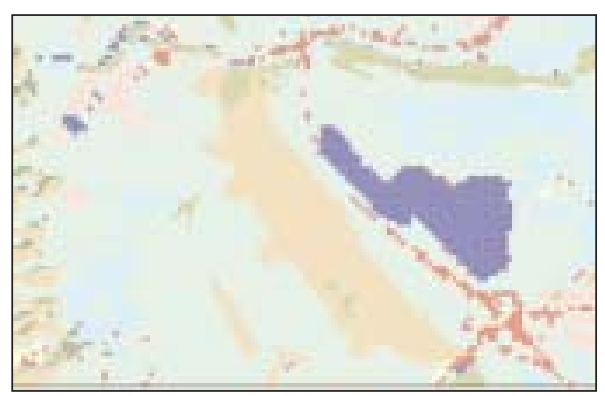

- Land cover data that classify the land surface into categories such as open water and high-density residential.

Changes affecting The National Map will be captured in near real time, rather than through cyclical inspection and revision. Currentness will be measured in days and months.

Data will be seamless and consistently classified, enabling users to extract information for irregular geographic areas, such as counties or drainage basins, and to spatially analyze the information. Data resolution and completeness will vary depending on geographic area and need. For example, The National Map will contain higher resolution elevation data in areas of subtle relief variation, such as river flood plains, to support hydrographic modeling.

Positional accuracy will be sufficient to vertically and logically align features from different data themes. Thus, river course will correspond to land surface slope, and boundaries will align with corresponding features, such as roads or rivers. The National Map will contain data for many areas that surpass the standards that have been applicable to primary series topographic maps.

All content of The National Map will be documented by metadata that comply with Federal standards.

\section{Building, Maintenance, and Operations}

The initial version of The National Map will be based primarily on existing available data. As the initial version is improved, emphasis will shift to maintaining data currentness through continuous updating. Potential data sources include State and local governments, private industry, and local trained and certified volunteers.

\section{Access and Use}

The National Map will be accessible through the Internet all day, every day. The data will be in the public domain. Data procured from commercial sources will include unlimited distribution and use rights.

Users will be able to combine data from The National Map with geographic information available from other organizations, such as cadastral information from the Bureau of Land Management and socioeconomic data from the Bureau of the Census. The National Map will be a foundation to which all organizations can reference their information, such as land use data, school district boundaries, or wildlife population counts.

The USGS will continue the tradition of the primary series topographic map by providing a standard set of paper topographic maps and digital data products derived from The National Map. Customers will be able to create their own maps by defining a geographic area of interest, selecting unique combinations of data, and printing their maps at home or at kiosks that will be available locally at libraries, recreational suppliers, bookstores, and so on.

\section{Strategies}

The USGS will be the (1) guarantor of national data completeness, consistency, and accuracy; (2) organizer of component activities; (3) catalyst and collaborator for partnerships and business relationships; (4) integrator and certifier of data from all sources; and (5) data producer and owner when no other source exists. A Federal advisory committee will make recommendations on requirements, business processes, technology implementation, and skills development that support The National Map objectives.

The USGS will proactively seek partnerships and business arrangements with government agencies, the private sector, and other organizations to develop and operate The National Map. USGS staff will be located across the Nation to work directly with staff of other USGS disciplines, partner organizations, private industry, and universities.
Taking advantage of the ongoing convergence of broadband wireless communication, mass data storage, and geolocation capabilities in personal digital devices, the USGS will encourage the participation of organizations and private citizens to serve as a volunteer force for change detection, data compilation and validation.

\section{Vision and Commitment}

The National Map is a new perspective on geographic base information. By sharing its vision, the USGS affirms its dedication to refocusing and reinvigorating its efforts to meet the Nation's needs for this critical information. The USGS will consolidate and redefine its component mapping activities and seek creative partnerships to ensure that current, complete, consistent, and accurate information is available and useful to the Nation. It will take sustained commitment to achieve the full goals of The National Map vision. In the near future, the USGS and its partners will concentrate on improving data and map content and currentness for high priority areas, with emphasis on building long-term partnerships, and on improving data access and dissemination capabilities.

We welcome your comments on The National Map mission and strategies. You can view and download the full report at http://nationalmap.usgs.gov. Please share your thoughts about the vision with the USGS by e-mail at nationalmap@usgs.gov or by mail to USGS-National Map, MS-511 National Center, 12201 Sunrise Valley Drive, Reston, VA 20192.

\section{Information}

For information on these and other USGS products and services, call 1-888-ASK-USGS, use the Ask.USGS fax service, which is available 24 hours a day at 703-648-4888, or visit the general interest publications Web site on mapping, geography, and related topics at mac.usgs.gov/mac/isb/pubs/pubslists/.

For additional information, visit the ask.usgs.gov Web site or the USGS home page at www.usgs.gov. 